\title{
Increased sensitivity to erythromycin in Escherichia coli associated with the presence of the ColV,I-K94 virulence plasmid
}

\author{
C. E. ALFA, C. F. L. REAKES and R. J. ROWBURY*
}

Department of Botany and Microbiology, University College London, Gower Street, London WC1E 6BT

\begin{abstract}
Summary. Introduction of the virulence plasmid, ColV,I-K94, into Escherichia coli strains led to increased sensitivity to erythromycin. This was the result of increased passage of antibiotic into ColV,I-K94 ${ }^{+}$organisms because the plasmid effect was abolished in bacteria which had been made permeable by chemical treatment. Full sensitivity in $\mathrm{ColV}^{+}$strains appears to depend on the simultaneous presence of transfer and colicin components. Increased erythromycin sensitivity associated with the plasmid was demonstrated in organisms grown at $37^{\circ} \mathrm{C}$; the sensitivity of ColV,I$\mathrm{K}^{+} 4^{+}$organisms grown at $25^{\circ} \mathrm{C}$ was similar to that of the parent strain. Added $\mathrm{Mg}^{++}$or $\mathrm{Ca}^{++}$ions reversed erythromycin inhibition in strains with the basal level of sensitivity (i.e., the $\mathrm{Col}^{-}$parent grown at $25^{\circ} \mathrm{C}$ or $37^{\circ} \mathrm{C}$ or the ColV,I-K94 ${ }^{+}$ derivative grown at $25^{\circ} \mathrm{C}$ ) and in those with the plasmid-associated increase in sensitivity. Addition of phosphate or EDTA to broth increased erythromycin sensitivity in $\mathrm{Col}^{-}$and $\mathrm{ColV}, \mathrm{I}-\mathrm{K} 94^{+}$strains although the latter was affected most. Erythromycin was more inhibitory at $p \mathrm{H} 8.5$ than at $p \mathrm{H} \mathrm{7.4.} \mathrm{This} \mathrm{enhanced} \mathrm{activity}$ was more marked against the ColV,I-K94 ${ }^{+}$strain than against the $\mathrm{Col}^{-}$strain. The effects of growth in phosphate-containing medium and at alkaline $p \mathrm{H}$ were partially additive. We suggest that ColV,I-K94 ${ }^{+}$strains may be sensitive to erythromycin because ColV-specified proteins are extruded by a process of "self-promoted transfer" and that the effects of these proteins on the lipopolysaccharide component of the outer membrane facilitates antibiotic influx.
\end{abstract}

\section{Introduction}

Plasmids of the ColV group are of considerable medical and veterinary importance because they are believed to increase virulence of pathogenic strains of enterobacteria including Escherichia coli. Originally, Williams-Smith (1974) and WilliamsSmith and Huggins (1976) established that ColV ${ }^{+}$ strains of $E$. coli are more pathogenic than isogenic $\mathrm{Col}^{-}$strains for poultry and calves and that $\mathrm{ColV}^{+}$ organisms are invasive. Subsequently, Binns et al. (1979) and Williams (1979) confirmed that ColV ${ }^{+}$ organisms are more virulent for animals than are $\mathrm{Col}^{-}$ones. The following ColV-associated properties may contribute to increased pathogenicity: (1) a ColV-encoded iron chelation mechanism, found in some ColV ${ }^{+}$strains (Williams, 1979); (2) ColVassociated serum resistance (Binns et al., 1979); and (3) ColV-associated attachment properties

Received 19 Mar. 1986; accepted 1 Oct. 1986.

* Correspondence should be sent to R. J. Rowbury.
(Clancy and Savage, 1981) that may result from increased hydrophobicity (Tewari et al., 1985).

The plasmid ColV,I-K94 is a large (mol. wt. $93 \times$ $10^{6}$ ) F-like element that encodes derepressed transfer properties and the production of colicins $\mathrm{V}$ and Ia (and their immunity components). ColV,I-K94 (and several other ColV elements) also encodes the major outer membrane VmpA protein (Moores and Rowbury, 1982; Rowbury et al., 1985). Like other ColV plasmids, ColV,I-K94 is a virulence plasmid (Binns et al., 1979) that confers two of the potential virulence characters listed above (serum resistance and attachment) and two others - autoagglutination and, for some isolates, a mucoid colonial phenotype (Rowbury et al., 1985).

The macrolide antibiotic erythromycin, although active against most gram-positive bacteria, is less effective against many gram-negative bacteria. Gram-negative bacteria that show marked erythromycin sensitivity, such as Legionella pneumophila and Neisseria gonorrhoeae, have outer membranes permeable to hydrophobic agents (Maness and 
Sparling, 1973; Wolf-Watz et al., 1975; Miller, 1983). The hypothesis that erythromycin resistance in enterobacteria is due to outer membrane impenetrability is supported by several findings. First, spheroplasts are much more erythromycin-sensitive than are intact gram-negative bacteria (Guze and Kalmanson, 1964). Second, erythromycin sensitivity increases in deep rough mutants that allow hydrophobic molecules to cross their outer membranes (Nikaido and Nakae, 1979). Third, enterobacteria such as $E$. coli have a very sensitive cell site for erythromycin inhibition (Tanaka and Teraoka, 1968) and their growth would be inhibited if erythromycin reached the ribosomes. Erythromycin is more effective at alkaline $p \mathrm{H}$. The uncharged form of the antibiotic, which predominates at alkaline $p \mathrm{H}$, probably permeates through the bacterial envelope better (Sabath et al., 1968) and is more inhibitory to the ribosome (Mao and Wiegand, 1968). Therefore, we studied the effect of the ColV,I-K94 plasmid on the sensitivity to erythromycin of $E$. coli strains at neutral and alkaline $\mathrm{pH}$ values.

\section{Materials and methods}

\section{Bacterial strains and plasmids}

All strains were derivatives of Escherichia coli K12. Strains 1829, C600, P678-54 and D21e7 have been described previously (Moores and Rowbury, 1982; Rossouw and Rowbury, 1984). Strain 414 was derived from $E$. coli KH262 (a thr leu ColV,I-K94 ${ }^{+}$strain kindly provided by $\mathrm{Dr}$ K. G. Hardy) by curing with an SDS plus high temperature growth regimen (Tewari et al., 1985). Subsequently, plasmid ColV,I-K94 was re-transferred into strain 414 by conjugation as described by Rossouw and Rowbury (1984). In one case, plasmid ColV.I-K94 was cured from $E$. coli $1829 \mathrm{ColV}, \mathrm{I}-\mathrm{K} 94^{+}$(Tewari et al., 1985). Other plasmid-bearing derivatives of the strains were prepared by conjugation or transformation (Rossouw and Rowbury, 1984; Tewari et al., 1985). The plasmids used and their characteristics have been described by Rossouw and Rowbury (1984) and Rowbury et al. (1985).

\section{Growth media and methods}

The liquid medium used throughout was Nutrient Broth No. 2 (Oxoid; $25 \mathrm{~g} / \mathrm{L}$ ) (NB), solidified, where necessary, with Bacto Agar (Difco) $2 \% \mathrm{w} / \mathrm{v}$ to give nutrient agar (NA). Except where otherwise stated, NB

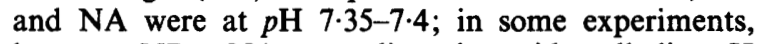
however, NB or NA were adjusted to acid or alkaline $p \mathrm{H}$ with $\mathrm{N} \mathrm{HCl}$ or $2 \mathrm{~N} \mathrm{NaOH}$.

Soft agar (Moores and Rowbury, 1982) was used for colicin and disk sensitivity tests (Multodisc; Oxoid).
Erythromycin sensitivity was assessed by overlaying NA plates with $4 \mathrm{ml}$ of soft agar containing the sensitive organisms $\left(10^{8} \mathrm{cfu} / \mathrm{ml}\right)$ placing a Multodisc on the surface and incubating at $37^{\circ} \mathrm{C}$. Zone sizes around Multodiscs were more reproducible on overlaid than on spread plates.

\section{Protein synthesis in permeable organisms}

Organisms were made permeable by plasmolysis with 2M sucrose (Wickner and Hurwitz, 1972) and treated organisms were tested immediately or after storage at $-20^{\circ} \mathrm{C}$. Protein synthesis was assayed by the method of Staudenbauer (1975) except that the amino-acid supplement was replaced by a ${ }^{14} \mathrm{C}$-protein hydrolysate (supplied by Amersham International and used at $5 \mu \mathrm{Ci} / \mathrm{ml} ; 56 \mu \mathrm{Ci} /$ mg Atom) supplemented with L-cysteine- $\mathrm{HCl}$, L-trytophan, L-methionine, L-glutamic acid and L-aspartic acid, each $0.5 \mathrm{~mm}$. Protein synthesis was tested at $37^{\circ} \mathrm{C}$ in the presence of appropriate levels of erythromycin. Samples were processed and counted as described by Staudenbauer (1975).

\section{Results}

\section{Erythromycin sensitivity of ColV,I-K $94^{+}$strains}

At an erythromycin concentration of $20 \mu \mathrm{g} / \mathrm{ml}$ in NA, many cells from $E$. coli strains 1829 , P678-54 and $\mathrm{C} 600$ formed colonies at $37^{\circ} \mathrm{C}$; with strain D21e7, 5-10\% of organisms formed colonies. The ColV,I-K94 plasmid, however, rendered the strains more sensitive to the drug (table I). This plasmid had a similar effect on $E$. coli 414 (data not shown) although the strain was already very sensitive to erythromycin. The increased erythromycin sensi-

Table I. ColV, I-K94-associated erythromycin sensitivity in $E$. coli

\begin{tabular}{lc}
\hline Strains & $\begin{array}{c}\text { Percentage of organisms } \\
\text { forming colonies on NA } \\
\text { erythromycin } 20 \mu \mathrm{g} / \mathrm{ml}\end{array}$ \\
\hline 1829 & 100 \\
1829 ColV,I-K94 & 3 \\
P678-54 & 66 \\
P678-54 ColV,I-K94 & 1 \\
C600 & 35 \\
C600 ColV, I-K94 & 1 \\
D21e7 & 7 \\
D21e7 ColV,I-94 & 0 \\
\hline
\end{tabular}

Organisms grown with shaking in broth at $37^{\circ} \mathrm{C}$ were plated (after dilution in $0.85 \%$ saline) on to NA+ erythromycin $20 \mu \mathrm{g} / \mathrm{ml}$ and colonies were counted after incubation at $37^{\circ} \mathrm{C}$ for $48 \mathrm{~h}$.

* Actual value for colony formation was $0.07 \%$. 
tivity was also apparent when antibiotic-impregnated disks were used; e.g., a $50-\mu \mathrm{g}$ disk (see Methods) produced a 6-mm zone of inhibition with strain C600 and an $8 \cdot 5-\mathrm{mm}$ zone with strain C600 ColV,I-K94 ${ }^{+}$.

Derivatives carrying plasmid ColV,I-K94 were also more sensitive to erythromycin than the parent strains when grown in NB. Table II shows that $E$. coli 1829 ColV,I-K $94^{+}$was markedly affected at $37^{\circ} \mathrm{C}$ by erythromycin $2 \cdot 5,5$ and $10 \mu \mathrm{g} / \mathrm{ml}$ whereas the effect on the parent strain 1829 was much less.

Table II. Erythromycin inhibition in liquid media; effect of ColV,I-K94

Percentage growth inhibition* with erythromycin

\begin{tabular}{lccc}
\cline { 2 - 4 } Strain & $2 \cdot 5 \mu \mathrm{g} / \mathrm{ml}$ & $5 \mu \mathrm{g} / \mathrm{ml}$ & $10 \mu \mathrm{g} / \mathrm{ml}$ \\
\hline 1829 & 14 & 42 & 49 \\
1829 ColV,I-K94 & & 78 & 88 \\
1829 cured $\dagger$ & 15 & 42 & 55 \\
1829 & & & \\
1829 ColV,I-K94 & NT & 42 & 53 \\
1829 ColV,I-K94 & NT & 64 & 79 \\
transformed & NT & 63 & 81 \\
& & & \\
\hline
\end{tabular}

NT $=$ not tested

* Organisms grown with shaking at $37^{\circ} \mathrm{C}$ were diluted to $c .3 \times$ $10^{7} \mathrm{cfu} / \mathrm{ml}$ and optical density followed in shaken cultures at $37^{\circ} \mathrm{C}$. Growth (cell mass increase) at $5 \mathrm{~h}$ is given as a percentage of that in the control without erythromycin.

+ This strain was derived by curing 1829 ColV,I-K94 ${ }^{+}$as described by Tewari et al. (1985).

\section{Erythromycin sensitivity of permeable organisms}

The ribosomes of $E$. coli $\mathrm{K} 12$ derivatives are very sensitive to inhibition by erythromycin (Tanaka and Teraoka, 1968; Tanaka et al., 1971); it seems likely, therefore, that the ColV,I-94 plasmid rendered the bacterial envelope more permeable to the drug, permitting it to reach the sensitive ribosomes. Studies with permeable cells confirmed this interpretation. Organisms made permeable by plasmolysis in concentrated sucrose behave as cell-free systems and allow free entry of hydrophobic inhibitors (Staudenbauer, 1975). Such preparations from $E$. coli strains 1829 and 1829 ColV,I-K94 ${ }^{+}$ incorporated labelled amino acids into TCAinsoluble material actively for at least $1 \mathrm{~h}$. ColV,IK94 did not increase the erythromycin sensitivity of such permeable organisms (table III).
Table III. Erythromycin effect on protein synthesis in permeable cells

\begin{tabular}{ccc}
\hline & \multicolumn{2}{c}{$\begin{array}{c}\text { Incorporation of }{ }^{14} \mathrm{C} \\
\text { (percentage of control*) }\end{array}$} \\
\cline { 2 - 3 } $\begin{array}{c}\text { Erythromycin } \\
\text { concentration } \\
(\mu \mathrm{g} / \mathrm{ml})\end{array}$ & E. coli 1829 & $\begin{array}{c}\text { E. coli } 1829 \\
\text { ColV,I-K94 }\end{array}$ \\
\hline 0 & 100 & 100 \\
$0 \cdot 25$ & 64 & 68 \\
$1 \cdot 0$ & 50 & 48 \\
$5 \cdot 0$ & 38 & 34 \\
\end{tabular}

* Incorporation of ${ }^{14} \mathrm{C}$ amino acids into TCAinsoluble material in permeable organisms was measured for $40 \mathrm{~min}$ at $37^{\circ} \mathrm{C}$ (see Methods) and recorded as a percentage of the incorporation into a control culture without erythromycin.

\section{Erythromycin sensitivity associated with plasmid ColV,I-K94}

Erythromycin sensitivity was thought to be due to the presence of the plasmid. An alternative possibility, that plasmid ColV,I-K94 had been preferentially transferred into erythromycin-sensitive mutant cells, was excluded by two findings : (1) a ColV,I-K $94^{+}$strain produced by transformation with plasmid DNA also showed increased erythromycin sensitivity (table II); and (2) a Col${ }^{-}$isolate derived from $E$. coli $1829 \mathrm{ColV}, \mathrm{I}-\mathrm{K} 94^{+}$by curing with heat and SDS (Rowbury et al., 1985) had a level of erythromycin sensitivity very similar to that of the parent $E$. coli strain (table II).

Organisms are more sensitive to erythromycin at alkaline $p \mathrm{H}$ (Sabath et al., 1968). The $p \mathrm{H}$ of cultures of $\mathrm{ColV}^{+}$strains may, therefore, have increased more than the $p \mathrm{H}$ of the cultures of $\mathrm{Col}^{-}$strains during growth in NB, rendering the $\mathrm{ColV}^{+}$strains more sensitive, but this proved not to be so. In a typical experiment, a culture of $E$. coli strain 1829 growing with erythromycin $5 \mu \mathrm{g} / \mathrm{ml}$ showed an increase in $p \mathrm{H}$ from 7.35 to 7.99 during the $5-\mathrm{h}$ incubation period at $37^{\circ} \mathrm{C}$ whereas the $p \mathrm{H}$ of an equivalent culture of $E$. coli strain $1829 \mathrm{ColV}, \mathrm{I}-$ $\mathrm{K} 94^{+}$increased from $7 \cdot 35$ to 7.79 during the same period.

\section{ColV component (s) responsible for erythromycin sensitivity}

The ColV,I-K94 plasmid confers several properties on $E$. coli that could lead to outer-membrane permeability changes (see Introduction). Tables IV and $\mathrm{V}$ show that the plasmid-associated erythro- 
Table IV. Plasmid components and erythromycin sensitivity

\begin{tabular}{|c|c|c|c|c|}
\hline \multirow[b]{2}{*}{ Strain } & \multirow{2}{*}{$\begin{array}{l}\text { Colicin and im- } \\
\text { munity compo- } \\
\text { nents }\end{array}$} & \multirow{2}{*}{$\begin{array}{c}\text { Transfer compo- } \\
\text { nents }\end{array}$} & \multicolumn{2}{|c|}{$\begin{array}{l}\text { Percentage growth inhi- } \\
\text { bition by erythromycin }\end{array}$} \\
\hline & & & $5 \mu \mathrm{g} / \mathrm{ml}$ & $10 \mu \mathrm{g} / \mathrm{ml}$ \\
\hline 1829 & None & None & 40 & 53 \\
\hline 1829 ColV,I-K94 ${ }^{+}$ & V \& Ia & Derepressed & 72 & 87 \\
\hline 1829 ColV-M40(5) ${ }^{+}$ & None & Derepressed & 49 & 63 \\
\hline 1829 ColV-M50(1) ${ }^{+}$ & V \& Ia & None & 20 & 38 \\
\hline $1829 \mathrm{Flac}^{+}$ & None & Derepressed & 50 & 59 \\
\hline 1829 & None & None & 48 & 56 \\
\hline 1829 ColV,I-K $94^{+}$ & V \& Ia & Derepressed & 67 & 85 \\
\hline $1829 \mathrm{R}_{483 \mathrm{Col} \mathrm{Ia}^{+}}$ & Ia & Repressed & 37 & 53 \\
\hline 1829 ColV-41 ${ }^{+}$ & V & Repressed & 43 & 61 \\
\hline
\end{tabular}

Organisms were grown at $37^{\circ} \mathrm{C}$ and percentage growth inhibition assessed as for table II.

mycin sensitivity is totally dependent on the presence of transfer components. A mutant form of ColV,I-K94 - ColV-M50(1) - which does not encode production of transfer components, did not cause increased erythromycin sensitivity (table IV). Indeed, $E$. coli 1829 ColV-M50(1) ${ }^{+}$appeared to be more resistant than the parent strain 1829 to erythromycin. The ColV,I-K94 effect was also reduced by the in $^{+}$plasmid $\mathrm{R} 124$ and abolished by the ColB-K98 plasmid (table V). Colicin components are also needed for sensitivity because $E$. coli 1829 ColV-M $40(5)^{+}$was less sensitive than strain 1829 ColV,I-K94 ${ }^{+}$(table IV).

Table V. Transfer components and erythromycin sensitivity

\begin{tabular}{|c|c|c|c|}
\hline \multirow[b]{2}{*}{ Strain } & \multirow{2}{*}{$\begin{array}{c}\text { Transfer } \\
\text { components }\end{array}$} & \multicolumn{2}{|c|}{$\begin{array}{l}\text { Percentage growth } \\
\text { inhibition by eryth- } \\
\text { romycin }\end{array}$} \\
\hline & & $5 \mu \mathrm{g} / \mathrm{ml}$ & $10 \mu \mathrm{g} / \mathrm{ml}$ \\
\hline 1829 & None & 35 & 50 \\
\hline $1829{\mathrm{ColV}, \mathrm{I}-\mathrm{K} 94^{+}}^{+}$ & Derepressed & 70 & 89 \\
\hline $1829 \mathrm{R} 124^{+}$ & Repressed & 47 & 62 \\
\hline 1829 ColV,I-K94, R124+ & Repressed & 52 & 71 \\
\hline 1829 & None & 35 & 48 \\
\hline 1829 ColV,I-K94 ${ }^{+}$ & Derepressed & 64 & 85 \\
\hline $1829{\text { ColB-K } 98^{+}}^{+}$ & Repressed & 32 & 47 \\
\hline $\begin{array}{l}1829 \text { ColV,I-K94, } \\
\text { ColB-K98 }\end{array}$ & Repressed & 30 & 51 \\
\hline
\end{tabular}

Growth and assessment of percentage growth inhibition were as for table II.
The presence of ColV-41 (a ColV plasmid from a sewage isolate of $E$. coli) did not confer sensitivity (table IV) although it encoded production of colicin $\mathrm{V}$ and its immunity component. Similarly, strain $1829 \mathrm{R}_{483} \mathrm{Colla}^{+}$, which produced colicin $1 \mathrm{a}$ and its immunity component, was erythromycin resistant (table IV).

\section{The effect of growth temperature on erythromycin sensitivity}

Growth of strain 1829 ColV,I-K94+ ${ }^{+}$was much less sensitive to inhibition by erythromycin when the cells had been previously grown at 25 or $30^{\circ} \mathrm{C}$ than when they had been grown at $37^{\circ} \mathrm{C}$. Strain 1829 showed similar sensitivity after growth at the three temperatures, whereas with strain 1829 ColV,I-K94 ${ }^{+}$, the culture that had been grown at $37^{\circ} \mathrm{C}$ was much more sensitive to erythromycin than were the other two (table VI).

\section{Reversal of erythromycin inhibition by increased $\mathrm{Mg}^{++}$or $\mathrm{Ca}^{++}$concentration}

Increasing the concentration of $\mathrm{Mg}^{++}$ions in growth media reduces the antibiotic sensitivity characteristic of certain classes of envelope mutants (Hancock, 1984); accordingly, the effect on erythromycin sensitivity of adding $\mathrm{Mg}^{++}$or $\mathrm{Ca}^{++}$salts to media was tested. Table VII shows that $\mathrm{MgSO}_{4}$ reduced the sensitivity to erythromycin of strain 1829 and strain $1829 \mathrm{ColV}, \mathrm{I}-\mathrm{K}^{\circ} 4^{+}$. At $10 \mathrm{mM}$, $\mathrm{MgSO}_{4}$ produced substantial reversal of inhibition (table VII) and $\mathrm{MgCl}_{2}$ had the same effect (results not shown). Calcium salts had a similar reversing 
Table VI. Effect of prior growth temperature on erythromycin sensitivity

\begin{tabular}{lcc}
\hline Strain & $\begin{array}{c}\text { Prior growth } \\
\text { temperature } \\
\left({ }^{\circ} \mathrm{C}\right)\end{array}$ & $\begin{array}{c}\text { Percentage growth inhi- } \\
\text { bition* by erythromycin } \\
10 \mu \mathrm{g} / \mathrm{ml}\end{array}$ \\
\hline 1829 & 25 & 36 \\
& 30 & 44 \\
1829 ColV,I-K94 & & 42 \\
& 37 & 54 \\
& 25 & 58 \\
& 30 & 81 \\
\hline
\end{tabular}

Organisms were grown in NB with shaking at the stated temperature and then diluted to $c .3 \times 10^{7} \mathrm{cfu} / \mathrm{ml}$ in fresh NB with erythromycin and incubation continued with shaking at $37^{\circ} \mathrm{C}$.

* Percentage growth inhibition defined as for table II.

effect (table VII); a $3 \mathrm{~mm}$ concentration caused substantial reversal of erythromycin inhibition of strain $1829 \mathrm{ColV}, \mathrm{I}-\mathrm{K} 94^{+}$. Both $\mathrm{Ca}^{++}$and $\mathrm{Mg}^{++}$ salts $(20 \mathrm{~mm})$ also reversed the limited erythromycin effect on organisms of both strains that had been grown at $25^{\circ} \mathrm{C}$.

Table VII. Reversal of erythromycin inhibition by $\mathrm{Mg}^{++}$or $\mathrm{Ca}^{++}$salts

\begin{tabular}{|c|c|c|c|c|}
\hline \multirow[b]{2}{*}{ Strain } & \multicolumn{2}{|c|}{$\begin{array}{c}\text { Divalent cations } \\
\text { added (mM) }\end{array}$} & \multicolumn{2}{|c|}{$\begin{array}{l}\text { Percentage growth in- } \\
\text { hibition with erythro- } \\
\text { mycin }\end{array}$} \\
\hline & $\mathrm{Mg}^{++}$ & $\mathrm{Ca}^{++}$ & $5 \mu \mathrm{g} / \mathrm{ml}$ & $10 \mu \mathrm{g} / \mathrm{ml}$ \\
\hline 1829 & $\begin{array}{r}0 \\
10 \\
20 \\
50\end{array}$ & $\begin{array}{l}0 \\
0 \\
0 \\
0\end{array}$ & $\begin{array}{l}\text { NT } \\
\text { NT } \\
\text { NT } \\
\text { NT }\end{array}$ & $\begin{array}{l}54 \\
33 \\
20 \\
13\end{array}$ \\
\hline 1829 ColV,I-K94 ${ }^{+}$ & $\begin{array}{r}0 \\
10 \\
20 \\
50\end{array}$ & $\begin{array}{l}0 \\
0 \\
0 \\
0\end{array}$ & $\begin{array}{l}64 \\
41 \\
32 \\
18\end{array}$ & $\begin{array}{l}\text { NT } \\
\text { NT } \\
\text { NT } \\
\text { NT }\end{array}$ \\
\hline 1829 & $\begin{array}{l}0 \\
0 \\
0\end{array}$ & $\begin{array}{r}0 \\
10 \\
20\end{array}$ & $\begin{array}{l}\text { NT } \\
\text { NT } \\
\text { NT }\end{array}$ & $\begin{array}{r}42 \\
21 \\
9\end{array}$ \\
\hline $1829 \mathrm{ColV}, \mathrm{I}-\mathrm{K} 94^{+}$ & $\begin{array}{l}0 \\
0 \\
0 \\
0\end{array}$ & $\begin{array}{r}0 \\
3 \\
10 \\
20\end{array}$ & $\begin{array}{l}65 \\
32 \\
20 \\
12\end{array}$ & $\begin{array}{l}\text { NT } \\
\text { NT } \\
\text { NT } \\
\text { NT }\end{array}$ \\
\hline
\end{tabular}

$\mathrm{NT}=$ not tested.

Organisms were grown with shaking in $\mathrm{NB}$ with $\mathrm{MgSO}_{4}$ or $\mathrm{CaCl}_{2}$ at $37^{\circ} \mathrm{C}$ and percentage growth inhibition assessed as for table II.
The NB used in the above experiments contained low but detectable concentrations of $\mathrm{Mg}^{++}$and $\mathrm{Ca}^{++}$ions (c. $0.1 \mathrm{mM} \mathrm{Mg}^{++}$salts and $0.08 \mathrm{mM}$ $\mathrm{Ca}^{++}$salts) that might have interfered with erythromycin inhibition. The broth was treated, therefore, to remove or chelate divalent cations. Organisms were more sensitive to inhibition by the antibiotic in NB to which phosphate had been added to precipitate $\mathrm{Mg}^{++}$and $\mathrm{Ca}^{++}$ions. Strain 1829 and its ColV,I-K94 ${ }^{+}$derivative were more sensitive in this medium but the effect seemed to be greater for the $\mathrm{ColV}^{+}$strain (table VIII). EDTA had a similar effect; at $0.5 \mathrm{~mm}$ it increased growth inhibition of strain 1829 in $\mathrm{NB} p \mathrm{H} 7.4$ by erythromycin $10 \mu \mathrm{g} / \mathrm{ml}$ from $42 \%$ to $91 \%$ and of strain 1829 ColV,I-K $94^{+}$by erythromycin $5 \mu \mathrm{g} / \mathrm{ml}$ from $38 \%$ to $96 \%$.

Table VIII. Erythromycin sensitivity; effects of alkaline $p \mathrm{H}$ and of added phosphate

\begin{tabular}{|c|c|c|c|c|}
\hline \multirow[b]{3}{*}{ Strain } & \multirow{3}{*}{$\begin{array}{l}\text { Initial } \\
p \mathrm{H} \text { of } \\
\mathrm{NB}\end{array}$} & \multirow{3}{*}{$\begin{array}{l}\text { Phosphate } \\
\text { (65 mM) } \\
\text { added } \\
\text { to NB }\end{array}$} & \multicolumn{2}{|c|}{$\begin{array}{l}\text { Percentage growth } \\
\text { inhibition with } \\
\text { erythromycin }\end{array}$} \\
\hline & & & $2 \cdot 5$ & $5 \cdot 0$ \\
\hline & & & $\mu \mathrm{g} / \mathrm{ml}$ & $\mu \mathrm{g} / \mathrm{ml}$ \\
\hline \multirow[t]{4}{*}{1829} & $7 \cdot 35$ & No & NT & 33 \\
\hline & $7 \cdot 35$ & Yes & NT & 52 \\
\hline & $8 \cdot 4$ & No & NT & 63 \\
\hline & $8 \cdot 4$ & Yes & NT & 76 \\
\hline \multirow[t]{4}{*}{1829 ColV,I-K94 } & $7 \cdot 35$ & No & 34 & NT \\
\hline & $7 \cdot 35$ & Yes & 67 & NT \\
\hline & $8 \cdot 4$ & No & 75 & NT \\
\hline & $8 \cdot 4$ & Yes & 95 & NT \\
\hline
\end{tabular}

NT $=$ not tested,

Organisms were grown with shaking at $37^{\circ} \mathrm{C}$ in $\mathrm{NB}$, with or without sodium phosphate, at $p \mathrm{H} 7.35$ or 8.4 , and with erythromycin.

Enhanced effect of erythromycin on strain 1829 ColV,I-K94 ${ }^{+}$at alkaline $\mathrm{pH}$

Erythromycin acts more effectively on gramnegative bacteria at alkaline $p \mathrm{H}$ (Sabath et al., 1968). All the experiments described above were

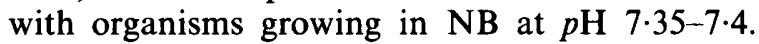
Strains 1829 and 1829 ColV,IK94 ${ }^{+}$tested with erythromycin at alkaline $p \mathrm{H}$ showed greater sensitivity (table VIII). Strain 1829 ColV,I-K94 ${ }^{+}$remained more sensitive than strain 1829 at $p \mathrm{H} 8.4$ and this alkaline $p \mathrm{H}$ appeared to enhance sensitivity of the $\mathrm{ColV}^{+}$strain more than that of the $\mathrm{Col}^{-}$ 
parent (table VIII). Increased sensitivity to erythromycin of strain $\mathrm{C} 600$ and its ColV,I-K94 ${ }^{+}$ derivative at alkaline $p \mathrm{H}$ in $\mathrm{NB}$ was also observed (results not shown). The effects of alkaline $p \mathrm{H}$ and of added phosphate were partially additive with strains 1829 and $1829 \mathrm{ColV},-\mathrm{K} 94^{+}$(table VIII).

Erythromycin sensitivity at alkaline $p \mathrm{H}$ was, like

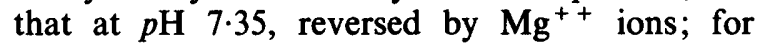
organisms growing in NB at $p \mathrm{H} 8.4,20 \mathrm{mM} \mathrm{MgSO}_{4}$ reduced the growth inhibition produced by erythromycin $10 \mu \mathrm{g} / \mathrm{ml}$ from $73 \%$ to $50 \%$ with strain 1829 and from $93 \%$ to $45 \%$ with strain 1829 ColV,I$\mathrm{K} 94^{+} . \mathrm{CaCl}_{2}(20 \mathrm{~mm})$ had a similar effect.

\section{Discussion}

The erythromycin sensitivity of $E$. coli strain 1829 ColV,I-K94 ${ }^{+}$resulted from the presence of the plasmid (table II) which rendered the organisms permeable to the antibiotic (table III). This erythromycin sensitivity was totally dependent on plasmid ColV,I-K94 transfer components (tables IV and V) and somewhat enhanced by colicin components (table IV). The finding that growth at 25 or $30^{\circ} \mathrm{C}$ abolished the plasmid effect is in keeping with the above, because synthesis of transfer and colicin components is reduced at 25 and $30^{\circ} \mathrm{C}$ (Tewari et al., 1985).

Hancock (1984) proposed that certain agents (e.g., polymyxins and aminoglycosides) enter gramnegative bacteria by a process which may be termed

\section{REFERENCES}

Binns, M M, Davies, D L, Hardy K G 1979. Cloned fragments of the plasmid ColV,I-K94 specifying virulence and serum resistance. Nature 279: 778-781.

Clancy J, Savage D C 1981 Another colicin V phenotype: in vitro adhesion of Escherichia coli to mouse intestinal epithelium. Infection and Immunity 32: 343-352.

Guze L B, Kalmanson G M 1964 Action of erythromycin on "protoplasts" in vivo. Science 146: 1299-1300.

Hancock R E W 1984 Alterations in outer membrane permeability. Annual Review of Microbiology 38: 237-264.

Mao J C-H, Wiegand R G 1968 Mode of action of macrolides. Biochimica et Biophysica Acta 157: 404-413.

Maness M J, Sparling P F 1973 Multiple antibiotic resistance due to a single mutation in Neisseria gonorrhoeae. Journal of Infectious Diseases 128: 321-330.

Miller R D 1983 Legionella pneumophila cell envelope: permeability to hydrophobic molecules. Current Microbiology 9: 349-354.

Moores J C, Rowbury R J 1982 A new major outer membrane protein in derivatives of Escherichia coli carrying the virulence plasmid ColV,-K94. Zeitschrift für Allgemeine Mikrobiologie 22: 465-475.

Nikaido H, Nakae T 1979 The outer membrane of Gram- "self-promoted transfer", whereby catonic groups on the agents cause the dissociation and separation of groups of lipopolysaccharide (LPS) molecules. Hydrophobic agents may also enter such cells in association with these cationic agents. Proteins extruded from cells might also traverse the LPS leaflet by such "self-promoted transfer" and, if the colicins, immunity components or transfer components encoded by the ColV plasmids used such an extrusion mechanism, this might allow concomitant entry of erythromycin.

If erythromycin entered $E$. coli ColV,I-K94 ${ }^{+}$ strains by such a mechanism, agents which stabilise LPS-LPS bonds might reduce antibiotic influx and sensitivity; this was observed with $\mathrm{Mg}^{++}$and $\mathrm{Ca}^{++}$ions. In contrast, treatments that weaken LPS-LPS bonds should have sensitised cells to the antibiotic; the effects of phosphate and EDTA were in keeping with this hypothesis.

Erythromycin has been used, in conjunction with alkalinisation, to treat urinary infections (Sabath $e t$ al., 1968). The availability of other active agents led to its replacement but the present findings suggest that urinary infections with strains of $E$. coli carrying virulence plasmids may be susceptible to erythromycin.

We are grateful to the Department of Medical Microbiology, University College Hospital; Imperial Chemical Industries plc; and the Central Research Fund of the University of London for financial assistance, and to the Medical Research Council for a partnership award to C.F.L.R. negative bacteria. Advances in Microbial Physiology 20: $163-250$

Rossouw F T, Rowbury R J 1984 Effects of the resistance plasmid R124 on the level of the OmpF outer membrane protein and on the response of Escherichia coli to environmental agents. Journal of Applied Bacteriology 56: 63-79.

Rowbury R J, Deeney C M, Reakes C, Rossouw F T, Smith D G, Tewari R 1985 Envelope protein changes, autoagglutination, sensitivity to hydrophobic agents and a conditional division lesion in Escherichia coli strains carrying ColV virulence plasmids. Annales de l'Institut Pasteur Microbiologie 136A: 147-157.

Sabath L D, Lorian V, Gerstein D, Loder P B, Finland M 1968 Enhancing effect of alkalinization of the medium on the activity of erythromycin against gram-negative bacteria. Applied Microbiology 16: 1288-1292.

Staudenbauer W L 1975 Novobiocin-a specific inhibitor of semiconservative DNA replication in permeabilized Escherichia coli cells. Journal of Molecular Biology 96: 201-205.

Tanaka K, Teraoka H 1968 Effect of erythromycin on polylysine synthesis directed by polyadenylic acid in an Escherichia coli cell-free system. Journal of Biochemistry (Tokyo) 64: 635-648.

Tanaka K, Teraoka H, Tamaki M, Takata R, Osawa S 1971 Phenotypes represented by a mutational change in a $50 \mathrm{~S}$ 
ribosomal protein component, 50-8, in Escherichia coli. Molecular and General Genetics 114: 9-13.

Tewari R, Smith D G, Rowbury R J 1985 Effect of ColV plasmids on the hydrophobicity of Escherichia coli. FEMS Microbiology Letters 29: 245-249.

Wickner R B, Hurwitz J 1972 DNA replication in Escherichia coli made permeable by treatment with high sucrose, Biochemical and Biophysical Research Communications 47: 202-211.

Williams, P H 1979 Novel iron uptake system specified by ColV plasmids: an important component in the virulence of invasive strains of Escherichia coli. Infection and Immunity 26: 925-932.
Williams Smith H 1974 A search for transmissible pathogenic characters in invasive strains of Escherichia coli: the discovery of a plasmid-controlled toxin and a plasmidcontrolled lethal character closely associated, or identical, with colicine V. Journal of General Microbiology 83: 95-111.

Williams Smith H, Huggins M B 1976 Further observations on the association of the colicine V plasmid of Escherichia coli with pathogenicity and with survival in the alimentary tract. Journal of General Microbiology 92: 335-350

Wolf-Watz H, Elmros T, Normark S, Bloom G D 1975 Cell envelope of Neisseria gonorrhoeae: outer membrane and peptidoglycan composition of penicillin-sensitive and -resistant strains. Infection and Immunity 11 : 1332-1341. 